\title{
$\mathrm{LR}=$ INTERNATIONAL JOURNAL OF ACADEMIC

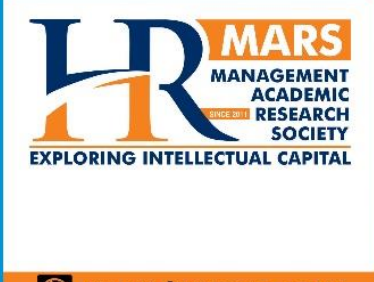

\&ww.hrmars.com

ISSN: 2225-8329

\section{Relationship between Managerial Roles and Job Satisfaction among Employees: Case Study of A Local Bank Headquarters in Kuala Lumpur, Malaysia}

\author{
Mohd Hafiz Zulfakar, Farah Dini Ezzati Abd Shukor, Janiffa Saidon, Abdul \\ Hafaz Ngah
}

To Link this Article: http://dx.doi.org/10.6007/IJARAFMS/v11-i3/10470

DOI:10.6007/IJARAFMS /v11-i3/10470

Received: 08 June 2021, Revised: 10 July 2021, Accepted: 25 July 2021

Published Online: 19 August 2021

In-Text Citation: (Zulfakar et al., 2021)

To Cite this Article: Zulfakar, M. H., Shukor, F. D. E. A., Saidon, J., \& Ngah, A. H. (2021). Relationship between Managerial Roles and Job Satisfaction among Employees: Case Study of A Local Bank Headquarters in Kuala Lumpur, Malaysia. International Journal of Academic Research in Accounting Finance and Management Sciences, 11(3), 48-61.

\section{Copyright: (C) 2021 The Author(s)}

Published by Human Resource Management Academic Research Society (www.hrmars.com)

This article is published under the Creative Commons Attribution (CC BY 4.0) license. Anyone may reproduce, distribute, translate and create derivative works of this article (for both commercial and non-commercial purposes), subject to full attribution to the original publication and authors. The full terms of this license may be seen

at: $\underline{\text { http://creativecommons.org/licences/by/4.0/legalcode }}$

\section{Vol. 11, No. 3, 2021, Pg. 48 - 61}




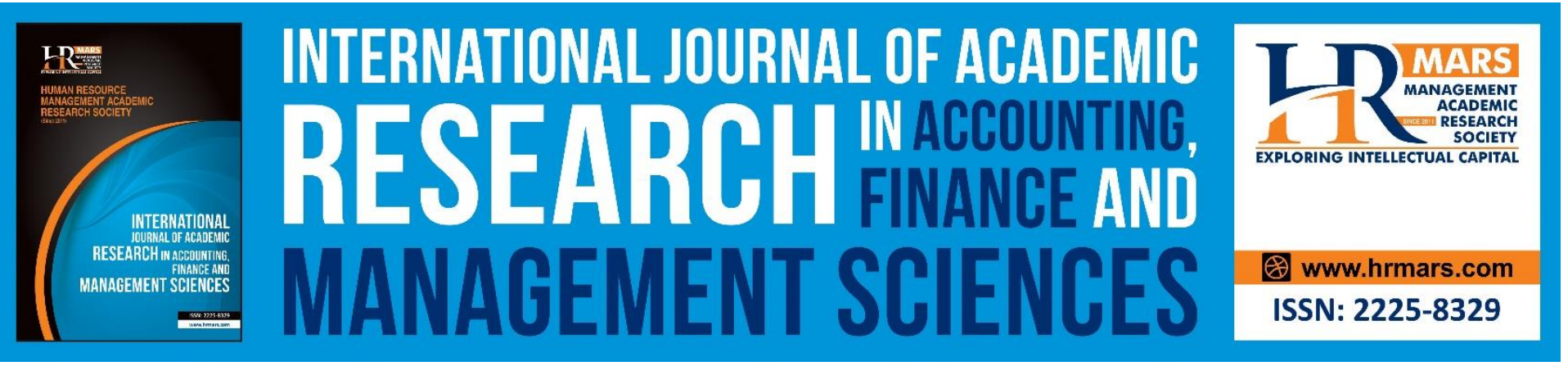

\title{
Relationship between Managerial Roles and Job Satisfaction among Employees: Case Study of A Local Bank Headquarters in Kuala Lumpur, Malaysia
}

\author{
Mohd Hafiz Zulfakar, Farah Dini Ezzati Abd Shukor, Janiffa Saidon \\ Faculy of Business and Management, Universiti Teknologi Mara UiTM Cawangan Selangor, Puncak \\ Alam Campus, Bandar Puncak Alam, Selangor, Malaysia \\ Email:mohdhafiz@uitm.edu.my, researchhz78@gmail.com
}

\begin{abstract}
Abdul Hafaz Ngah
Faculty of Business, Economy and Social Development, Universiti Malaysia Terengganu, Kuala Nerus, Terengganu, Malaysia

Email: hafazngah@gmail.com
\end{abstract}

\begin{abstract}
A strong financial institution plays a significant roles in stimulating the development and economic growth for a given country. As the economy moves into a new era where industrialization are accelerated and the privatization initiative are seen moving forward drastically, definitely it gave influence to the employees' job satisfaction. Despite the large amount of research that has been carried out to investigate the relationship between managerial roles and job satisfaction, limited research has been conducted from the perspective of banking industry in developing countries such as Malaysia. This present study provides insights on the relationship between managerial roles and employee job satisfaction. Based on Mintzberg's managerial roles view, this study posits that managerial roles (interpersonal, informational and decisional) strongly influenced job satisfaction in an organization. Using stratified random sampling method, survey questionnaires were used to collect data from 123 respondents working in the headquarters of a renowned leading local bank in Kuala Lumpur. Multiple regression analysis was used for hypotheses testing and found that informational roles and decisional roles indeed showed significant positive relationship towards employees' job satisfaction. However, no relationship was found between interpersonal role and employees' job satisfaction. Recommendations have been made to encourage managers to play their role in ensuring employees job satisfaction in banking industry. This paper offers avenue for future researcher to employ the current research framework but looking into the comparison on level of satisfaction between gender among the target respondent.
\end{abstract}

Keyword: Job Satisfaction, Managerial Roles, Interpersonal, Informational, Decisional, Banking, Kuala Lumpur 
INTERNATIONAL JOURNAL OF ACADEMIC RESEARCH IN ACCOUNTING, FINANCE AND MANAGEMENT SCIENCES

Vol. 11, No. 3, 2021, E-ISSN: $2225-8329$ @ 2021 HRMARS

\section{Introduction}

Job satisfaction is one of the important factors which have drawn managers attention as the industry practitioners as well as the academicians. Job satisfaction is one of the psychological inclinations to positivity in which a person has about his or her activity (Coplan et al., 2018). It is frequently said that a happy employee is a productive employee. A profoundly fulfilled laborer has better physical and mental prosperity. In order for an organization to be as effective, it must constantly ensure the satisfactorily of their employees (Kalluvelil \& George, 2011). The more joyful the laborers, the more fulfilled they are, as a fulfilled specialist is additionally a productive worker. Organization with increasingly fulfilled representatives will in general be progressively viable as laborers are spurred and resolved to work for the organization (Al-Sada, Al-Esmael, \& Faisal, 2017).

In current global situation, every organization understands in which it is vital in retaining their respective laborer fulfilled as human asset is significant resources on behalf of institute to ensure their business are ongoing. The satisfied specialists for the most part convey better quality administrations to the clients. Consumer loyalty is significant as it is fundamental in building long haul, productive connections eventually prompting client steadfastness and rehash business (Kassahun, 2019). According to Smith, Kendall and Hulin (1969) found that as for the personnel, job satisfaction is essential to the operatives' psychological well-being.

Managers play multiple roles, specifically at upper levels in their organization (Mintzberg, 1973). Besides settling exact tasks assigned to them such as those linked to functions like production, marketing, personal management or financed, the managers also play roles related to operation, leadership, strategies and others (Annuar, 2011). The performance of a manager depends significantly on how well he or she plays the multiple roles on the organization (Alatailat, Elrehail \& Emeagwali, 2019). Thus, the performance give impact on how well these roles are played by the manager in their organization.

Mintzberg (1990) classified a manager's duties or "roles" into communicating handling information, communicating with people and making decision. However, it should be bear in mind that roles do not occur in every manager as they are interrelated and interdependent in such a way that it is legitimate to describe the nature of managerial actions and responsibilities by taking into account the levels of management and the specificity of the production processes. Therefore, it is possible to define different types of manager with the help of widespread roles. For instance, a manager who rank high on initiating structure but low on consideration are more likely to be engaged in decisional roles, and less in informational interpersonal roles (Mansor, Mansor \& Roslan, 2019).

The key success of a company or an organization in its day-to-day operation and future planning, regardless of the industry type is managerial roles (Rania, Taghrid \& Mohammed, 2018). An employee who are under good supervision will lead to the successful of the organization and also will increase the degree of employee satisfaction (Kiarie, Maru \& Cheruiyot, 2017).

In recent years, employee job satisfaction has transformed into an imperative corporate target. Associations can arrive at target when their workers are submitted, and difficult work can be possible just when they are content with their employments. Job satisfaction is a strategy to draw in and hold 
INTERNATIONAL JOURNAL OF ACADEMIC RESEARCH IN ACCOUNTING, FINANCE AND MANAGEMENT SCIENCES

Vol. 11, No. 3, 2021, E-ISSN: 2225-8329 @ 2021 HRMARS

the top social orders in the association. Job satisfaction can be very much characterized as a productive energetic response from the assessment of a livelihood on how much an individual likes their action (Hugnes, 2006). Employee job satisfaction is a key for association since it in the long run consequences for its turn of events. Workers are progressively stressed with their employments now and think to get more fulfillment contrast with past. Job satisfaction is presently a hotspot for them to remain in the ongoing association or leave it for another (Febres, 2017). Job satisfaction has fundamental impact on employees' profitability and associations that have extraordinary workers superior than other organizations (Shehawy, 2018).

There are many different styles in the relationship of managerial roles and employee satisfaction that are based on different theories and assumptions. The style that an individual uses will be based on a combination of his or her values, beliefs, and preferences, as well as the organizational norms and culture which will encourage some styles and discourage others. Based on study by Abdullah, Musa, Zahari, Rahman and Khalid (2011), 87.4\% and 86.1\% of employees' satisfaction in terms of supervisor treat them with respect and fairly and $81.6 \%$ and $80.4 \%$ of employee satisfaction for opportunity to learn and grow and feel like one family that shared goal, factor highly contribute to employee satisfaction. According to Annuar (2011), employees will have high job satisfaction if they believe that the organization they are working for, give credit to the quality of their work and this employee will be more committed to the organization.

This study seeks to look at the relationship between managerial roles and employees' job satisfaction, in order to identify the best element that need to be implemented and used in the day to day working environment in an organization.

\section{Literature Review \\ Managerial Roles}

The managerial roles are the main part in the success of the organization as it leads its employees towards the organization's objective, vision and mission. Employees will be satisfied and achieve success when the right management can lead and guide them throughout their working career.

Managers have to undertake several sorts of activities in order to accomplish the objective of the organization and to ensure their roles are successful. The theory of management roles introduced by Mintzberg (1990) will be used in this research. These roles are common in all managerial job regardless of the functional of hierarchical level. A manager's job consists of several parallel roles. But, at a certain point in time, the manager may perceive one role as more essential than the others.

However, decades of research have failed to not only establish a strong link, in terms of affecting size between job satisfaction and performance, but also to find a clear connection within the body of evidence between employee job satisfaction and performance (Mariya \& Svetlana, 2000). Although there is support in the literature to recommend that a relationship does exist between job satisfaction and employee performance, the empirical evidence, the notion that happy workers are more productive is formally entrenched in the management ideology (Wright \& Cropanzo, 2000). 
INTERNATIONAL JOURNAL OF ACADEMIC RESEARCH IN ACCOUNTING, FINANCE AND MANAGEMENT SCIENCES

Vol. 11, No. 3, 2021, E-ISSN: 2225-8329 @ 2021 HRMARS

In understanding the activities of the manager, it is necessary to develop beyond function to determine how it is expressed. For this, the work of Mintzberg (1973) can be applied to illuminate how a manager performs this function. Mintzberg (1973) proposed a combination of ten different roles utilized by a manager to accomplish their objectives. These roles can be gathered into three broader groups based on how well the information is handled.

Figure 1: Mintzberg's Managerial Roles

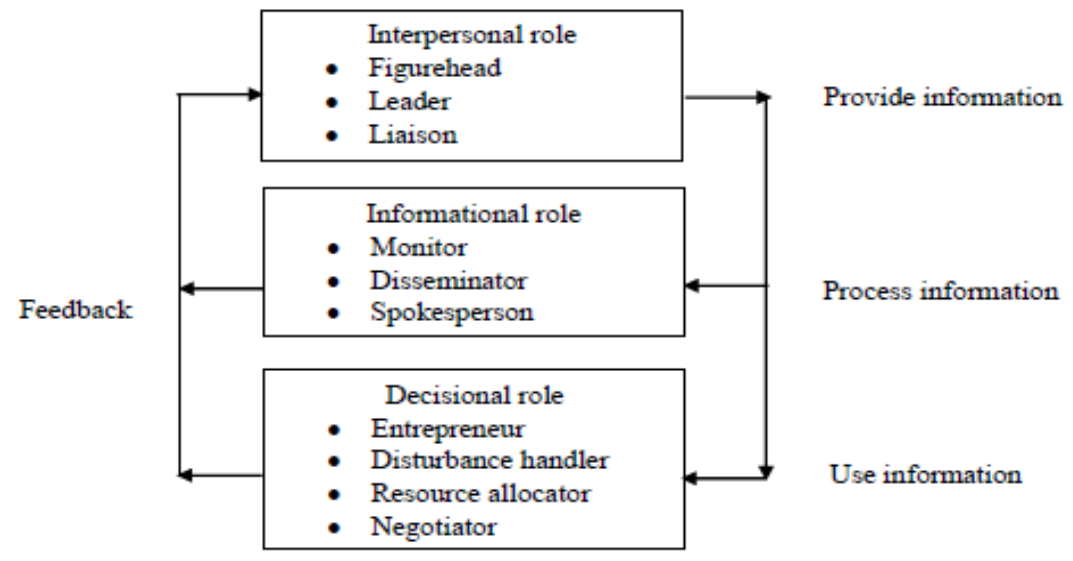

The interpersonal role recommended by Mintzberg (1990) imply the managers make contacts with various individuals, both internal and external, in the unit they lead. Although such contacts have been fundamentally connected with formal position, it distinguishes that initiative will likewise characterize the degree to which directors is such a wellspring of intensity (Mintzberg, 1990). In a research done by McConkey (2002) using the managerial roles theory by Mintzberg (1973), the result showed that interpersonal role is the highest significant factor in the relationship between managerial roles and employees' job satisfaction. According to McConkey (2002), a manager who spends more time performing these roles lead to better employee job satisfaction than managers that do not spend more time adopting these roles.

On the other hand, Mintzberg (1973) stated that the information role captures the managers' activity in acquiring and disseminating information and will thus vary with the need for information. Bakers (2001) stated that in playing informational roles, managers communicate and receive information. By obtaining relevant and important information from the networks, managers are able to implement their agendas. According to McGinn (2003), a manager must assist as the key informational link between the organization and the employees. A manager who does not adopt informational role makes employees dissatisfied with the manager. McGinn (2003) found a significant positive relationship between managers and employees. As Mace (2013) points out that managers are turns who possess the central situation and, in this manner, have rights to all data regarding their foundations. Robbins and Judge (2013) sustain that in this category of managerial roles, managers' act as monitors, disseminators and spokespersons of their organizations.

The last four managerial sub-roles in Mintzberg's model: entrepreneur, disturbance handler, resource allocator, and negotiator, are categorized as decisional roles. Mintzberg (1973) describes 
INTERNATIONAL JOURNAL OF ACADEMIC RESEARCH IN ACCOUNTING, FINANCE AND MANAGEMENT SCIENCES

Vol. 11, No. 3, 2021, E-ISSN: 2225-8329 ๑ 2021 HRMARS

the undertakings in such fragment of role as likely the most dynamic piece of the supervisors. These roles setting tactics and making choices at all levels of the organization. They can be connected to the instructive jobs, for it is with assembled and shared data that the manager decides (Tovmasyan, 2017). The decisional roles categories are closely linked with the organization processes in the level of analysis. Decisional roles are needed in the organization processes in the organization especially for managers to resolve issues related to employees, places, policies, programs and processes (Rahman, 2019). A test done by Welch (2002) showed that when a manager makes a good and relevant decisions regarding and employees, it will benefit the two parties. He found a strong relationship between all the categories of decisional roles and managers, employees and the organization. Robbins and Judge (2013) agree with Mintzberg's and include that the decisional role of managers is those that settling on decisions for the association such as entrepreneurial, disturbance handlers, resource allocation and negotiating roles.

\section{Employees' Job Satisfaction}

Existing literature reveals that employee job satisfaction is the most crucial and necessities for an employee to be successful, productive and happy, and of course, have a wonderful inclination, which is a result of the impression of what the activity accommodates individual employee (Ming-Chun, Ching-Chan and Ya-Yuan, 2015). These authors came up with a definition of difference, which also refers to the degree of satisfaction and the difference between individual actual returns and the required one. Employee job satisfaction has been underlining on how employee think, observe feel their given task.

Considered the most significant resource since it assumes a significant job in the advancement of an association and society in general. Despite the fact that fund is viewed as the existence blood for an association, yet the best possible administration of these budgetary assets relies on its Human Resource. So, every organization needs to have the best Human Resource to accomplish its targets, yet this must be conceivable when it has a satisfied workforce on the grounds that a satisfied workforce applies more endeavors and strives to achieve organizational objectives (Dormann \& Zapf, 2001). The more the workers are happy with their occupations, the more endeavors they will apply to accomplish organizational objectives (Blakely et al., 2003), and satisfaction of employees with their jobs has direct affects the achievement of the association (Shaukat et al., 2016).

Organizations can make progress when its representatives are submitted, and difficult work can be conceivable just when they are content with their employments. Employees' job satisfaction is very important for organization because it ultimately impacts on its development. Compare to past, employees are increasingly worried about their employments now and hope to get more satisfaction. Employee job satisfaction has become a significant corporate in recent years. Manager personality traits might be a deciding variable in the achievement of an association in satisfying employees. Manager personality traits have a significant influence on the way managers relate, think, feel, see, and even respond to other people (Alkahtani, Abu-Jarad, Sulaiman, and Nikbin, 2016). Job satisfaction alludes to the earnest sentiments of a worker towards his work execution. Among all the various elements that have an effect on employee job satisfaction, managerial role has been viewed as one of the most significant and urgent in every organization. Several different studies which have been 
INTERNATIONAL JOURNAL OF ACADEMIC RESEARCH IN ACCOUNTING, FINANCE AND MANAGEMENT SCIENCES

Vol. 11, No. 3, 2021, E-ISSN: 2225-8329 @ 2021 HRMARS

carried out in various countries concluded that there is a positive correlation between managerial and employee job satisfaction (Mosadegh Rad \& Yarmohammadian, 2006).

There are several aspects can improve job satisfaction of employees' like working conditions, work itself, management, strategy and organization, headway, remuneration, relational connections, acknowledgment, and strengthening however pioneer character has a significant relationship to support representatives' activity fulfillment (Castillo, 2004). The quality of leader-employee relationship has a critical relatedness with employees' job satisfaction and workers feel fulfilled and alright with managers who are supportive (DeCremer, 2003). Employees feel pressure when they need to work with a manager who is unsupportive and whose behavior is negative. Negative leaderemployee relationship has different unfavorable effects on the workers as it decreases profitability, expands non-attendance and the turnover to the association can likewise be very high (Ribelin, 2003).

\section{Methodology}

This research was conducted for one of the local banks (Headquarters office) in Kuala Lumpur and the respondents are from selected departments in the company. During the initial investigation, the researchers distinguished the current practices and issues related to employee job satisfaction in the bank industry. Among all the local banks, the researcher observed that the chosen Headquarters office have received many bad reviews towards their managers and job related.

The population for this study is the total number of staffs from departments at the chosen local bank (Headquarters) in Kuala Lumpur. The total number for five departments selected is 181 persons (Refer Table 1). The selection of sample is based on stratified random sampling. This technique requires selecting population of the staff at selected departments in the Headquarters office in Kuala Lumpur. In this technique, each member of population involves a process of stratification whereby followed by random selection of subjects from each stratum. Since the Headquarters in Kuala Lumpur have two office, the researchers decided to pick departments that have many staffs and available in both Headquarters. Based on Krejcie and Morgan (1970) table for sample size from a population of 181 , the sample size for this study is 123 respondents.

Table 1: Populations for Each Department

\begin{tabular}{|l|l|}
\hline List of Department & Population \\
\hline Legal Department & 23 \\
\hline IT Department & 35 \\
\hline Human Resource Department & 38 \\
\hline Helpdesk Department & 45 \\
\hline SME Banking Department & 40 \\
\hline Total Population & 181 \\
\hline
\end{tabular}

The respondents were given two weeks $\left(15^{\text {th }}\right.$ to $30^{\text {th }}$ June 2020$)$ to complete the online survey. After the data cleaning process for any missing value, straight lining and suspicious responds, it was found that all 123 questionnaires were completed and usable by the researcher for final analysis. As a result, all 123 responses (100\%) were regarded as valid for further analysis. 
The dual language questionnaire consisted of three sections. Section A looking at the demographic factors such as age, education level and working experience. Section B consist of several items on managerial roles. The respondent were asked about three roles that were adapted from Mintzberg (1973) managerial roles, which are interpersonal role, informational role and decisional role and rate all the items on a 5-point Likert from "strongly agree" (1) to "strongly disagree" (5). The instrument was adapted from Chen and Wu (2008) and restructured according to the focus of the study. Section $C$ consists of items measuring job satisfaction. The items in this section were based on previous work in this area, which are from (Rahman, Akhter \& Khan, 2017).

\section{Results and Discussion \\ Respondents Profile}

The finding shows that out of 123 respondents, $69.9 \%$ were female, meanwhile $30.1 \%$ were male. This studied can explained that most of the respondents in this study were dominated by the female. Most of the respondents aged between 20-30 years old which was 65 (52.8\%) of them. This is followed by those who were 31-40 years old with 40 (32.5\%) respondents. Meanwhile, 18 (14.6\%) of the respondents aged between $41-50$ years old. There are none of the respondents that age 51 and above (0\%).

Most of the respondents worked in current department less than 3 years which was 56 (45.5\%) of them. This is followed by respondents that worked in current department 7-10 years with 29 (23.6\%). Meanwhile, 21 (17.1\%) of the respondent worked in current department more than 10 years. Only $17(13.8 \%)$ of the respondents worked in current department within 3-6 year. From the job position perspective, majority of the respondents are Junior Executive (44.7\%), followed by Senior Executive $(41.5 \%)$. Next the respondents with a position clerk/administration (5.7\%) and last is supervisor position with only $10(8.1 \%)$ respondents.

\section{Descriptive Analysis}

This section is to determine the level of managerial roles, whereby the elements of managerial roles consists of 29 questions and using scale of 1 to 5 (strongly disagree to strongly agree). The interpretation of the scores for Managerial Roles in the form of high score based on Best's Principle (Thaoprom, 2004). Based on the Table 2, the overall result shows that the score of managerial roles among respondents' at Headquarters Maybank Kuala Lumpur can be considered as high level that is 3.8217 (Scores between 3.68 - 5.00 = High Scores). In terms of Standard Deviation, the managerial roles indicates the scores of .67716. The result also shows the score of managerial roles namely interpersonal role was the highest $(M=3.9439, S D=.78272)$ followed by informational role $(M=3.7624$, $\mathrm{SD}=.97959)$ and decisional role $(\mathrm{M}=3.7528, \mathrm{SD}=1.01273)$. 
INTERNATIONAL JOURNAL OF ACADEMIC RESEARCH IN ACCOUNTING, FINANCE AND MANAGEMENT SCIENCES

Vol. 11, No. 3, 2021, E-ISSN: 2225-8329 @ 2021 HRMARS

Table 2: Level of Managerial Roles

\begin{tabular}{lcccc}
\hline Variables & $\mathbf{N}$ & Mean & Std. Deviation & Level \\
\hline Interpersonal Role & 123 & 3.9439 & .78272 & High \\
Informational Role & 123 & 3.7624 & .97959 & High \\
Decisional Role & 123 & 3.7528 & 1.01273 & High \\
& & & & \\
\hline Overall Managerial Roles & 123 & 3.8217 & .67716 & High \\
& & & & \\
\hline
\end{tabular}

The reliability analysis was conducted by computing the Cronbach's alpha for each measure. Reliability was used to measure the consistency and stability of the instrument which it measures the concept and evaluate the goodness of a measure (Sekaran \& Bougie, 2011). Table 3 shows the result for Cronbach Alpha for the first dimension of managerial roles that was interpersonal role .845, informational role .892 and decisional role .907 . For dependent variable which is employee job satisfaction is in the range of .950 . The reliability coefficient indicates that all the dimensions and variables were plotted between ranges of 0.845 to 0.950 which ultimately signify a high degree of reliability (Very Good to Excellent) (Sekaran \& Bougie, 2011).

Table 3: Cronbach's alpha scores

\begin{tabular}{clccc}
\hline Section & \multicolumn{1}{c}{ Scales } & $\begin{array}{c}\text { No. of } \\
\text { Items }\end{array}$ & $\begin{array}{c}\text { Cronbach's Alpha } \\
(\mathbf{n}=126)\end{array}$ & $\begin{array}{c}\text { Strength of } \\
\text { Associations }\end{array}$ \\
\hline B & Managerial Roles & & & \\
& Interpersonal Role & 10 & .845 & Very Good \\
& Informational Role & 9 & .892 & Very Good \\
& Decisional Role & 10 & .907 & Excellent \\
\hline C & Employee Job Satisfaction & 16 & .950 & Excellent \\
\hline
\end{tabular}

\section{Multiple Regression Analysis}

The objective of this study was to investigate which dimensions of managerial roles is the most influential on job satisfaction among employees' in the chosen local bank Headquarters in Kuala Lumpur. In this study, multiple regression was used to explore which variables in the managerial roles namely interpersonal role, informational role and decisional role is the best predictor of job satisfaction among employees at the chosen local bank Headquarters in Kuala Lumpur. 
INTERNATIONAL JOURNAL OF ACADEMIC RESEARCH IN ACCOUNTING, FINANCE AND

MANAGEMENT SCIENCES

Vol. 11, No. 3, 2021, E-ISSN: 2225-8329 @ 2021 HRMARS

Table 4: Multiple Regression Analysis

\begin{tabular}{|c|c|c|c|c|c|}
\hline \multirow[t]{2}{*}{ Independent Variable } & \multirow{2}{*}{$\begin{array}{c}\begin{array}{c}\text { Standardized } \\
\text { Coefficient }\end{array} \\
\text { Beta }\end{array}$} & \multirow[t]{2}{*}{ t } & \multirow[t]{2}{*}{ Sig. } & \multicolumn{2}{|c|}{ Collinearity Statistics } \\
\hline & & & & Tolerance & VIF \\
\hline Interpersonal Role & -.181 & -3.422 & .001 & .955 & 1.047 \\
\hline Informational Role & -.055 & -.907 & .366 & .741 & 1.349 \\
\hline Decisional Role & .867 & 14.313 & .000 & .732 & 1.367 \\
\hline $\mathrm{R}^{2}$ & & .681 & & & \\
\hline F Change & & 84.506 & & & \\
\hline Significance of $F$ value & & $.000^{\mathrm{b}}$ & & & \\
\hline
\end{tabular}

Table 4 above shows the results indicates that there was negative, no significant and no relationship between interpersonal role and employees' job satisfaction. This is due to $p$ value was more than 0.01 ( $r=.-.108,>0.01$ ). Therefore, $\mathrm{H} 1$ is not accepted.

For informational role, there was positive, weak and significant relationship with employees' job satisfaction. This is due to $\mathrm{p}$ value was less than $0.01(r=.353,<0.01)$. Therefore, H2 is accepted. In Bakers (2001), it is stated in playing informational roles, managers communicate and receive information. By obtaining relevant and important information from the networks, managers are able to implement their agendas.

According to Hill (2016), whatever issue that are happening within and without organization, managers always prepared and informed about the issues. They want adequate data consistently which will empower them to effortlessly manage issues tormenting the organization. Consequently, managers consistently have timely and adequate data to have the option to react successfully to occasions in their organizations.

Results for decisional role and employees' job satisfaction indicates that there was positive, very strong and significant relationship. This is due to $p$ value was less than $0.01(r=.803,<0.01)$. Therefore, $\mathrm{H} 3$ is accepted. A test done by Welch (2002) showed that when a manager makes a good and relevant decisions regarding and employees, it will benefits the two parties. He found a strong relationship between all the categories of decisional roles and managers, employees and the organization.

Besides, Paul (2017) mentioned that managers are principal decision-makers in organizations since they are constantly gone up against with surprising issues to fight with and even plan for actions to undertake in order to embrace so as to conquer such issues. For example, a conflict of interests between divisions or offices or between subordinates or an unforeseen interference to the conveyance of significant assets, will warrant managers to take quick choices that will settle such issues. When gone up against with such issues, managers at first actualize quick transient estimates that will quiet the circumstance so as to permit workers continue their obligations at the earliest opportunity. Over the long haul, they survey and look at issues profoundly to make basic changes and plan decides and approaches that will keep comparative issues from happening again in the future. 
Table 4 also indicates the multiple regression analysis between managerial roles and employee job satisfaction. The result indicates that $\mathrm{R}^{2}$ is .681 , which are all independent variables such as interpersonal role, informational role and decisional role explained $68.1 \%$ of the variance ( $R$ square) in managerial roles, with Sig. of $F$ value was .000 . From the result of this analysis, the researcher found that decisional role was the most influential dimension of the managerial roles on employee job satisfaction ( $p<0.05, \beta=.867)$ and followed by interpersonal role $(p<0.05, \beta-.181)$. However, informational role did not show significant influence on employees' job satisfaction as $p$ value was more than 0.05 for significance. Therefore, the result from this analysis indicates that decisional role was significantly contributed to the job satisfaction among employees at the chosen local bank Headquarters in Kuala Lumpur followed by the interpersonal role.

\section{Discussion}

This study shows the importance of relationship between the dimensions of managerial roles and employee job satisfaction at the chosen local bank Headquarters in Kuala Lumpur. The finding of this study may contribute to a better understanding of the relationship between two variables and also define the level of relationship. With this finding, managers can improve their weak role area to endure employees are satisfied and also to achieve organizational success.

Based on the findings, interpersonal role did not have significant relationship. Apart of that, it is the obligation of all levels of management to encourage a positive working environment condition. Managers must esteem the qualities of reliability and trust, strengthening and assignment, consistency and mentorship. These are the structure squares of any prospering association. It is well known that the banking environment has both dynamic and competitive nature, so managers should be focusing on providing employees with new and diverse skills and cognition, ensuring their flexibility to be able to respond to change. For managers, they have to learn how to provide the information in a good way. According to McConkey (2002), a manager who spends more time performing these roles lead to better employee job satisfaction than managers who do not spend more time adopting these roles.

However, there are two roles that have positive relationship with employees' job satisfaction which are informational role and decisional role. From here, it can be suggested that managers at the chosen local bank Headquarters in Kuala Lumpur know how to link the information between organization and employees. They know how to manage and handle the jobs with outsiders very well. Hence, they also do open sharing information and solution with employees whenever they have problem regarding the project.

Decisional role is another role that decide how good the managers handle the situation. From the results, employees satisfied with their managers in terms of problem solutions. It was shown clearly that employees are satisfied with their job according to their manager's treat. A good managerial practice will produce good managers who will lend the employees in the organization towards satisfaction. When manager can successfully approach their employees in a good way, the employees will feel appreciated and stay long in the organization. This will benefit the organization because the level of employee job satisfaction will affect performance and productivity. 
INTERNATIONAL JOURNAL OF ACADEMIC RESEARCH IN ACCOUNTING, FINANCE AND

MANAGEMENT SCIENCES

Vol. 11 , No. 3, 2021, E-ISSN: 2225-8329 @ 2021 HRMARS

\section{Conclusion}

This research study was conducted to determine the relationship between the dimensions of managerial roles and job satisfaction among employees at the chosen local bank Headquarters in Kuala Lumpur. There are three primary findings from the research in this study. Firstly, there are two (2) significant variables, namely informational role and decisional role, but one of the variables which interpersonal role are not significant to employees' job satisfaction. In this research, the researcher can conclude that, hypotheses 2 and 3 accepted but hypotheses 1 was not accepted.

The second conclusion is that informational role and decisional role and employees' job satisfaction results are linked. The correlation analysis (refer Table 4) shows that the relationship between two elements under dimensions of managerial roles (informational role and decisional role) are significant and have a relationship with dependent variables. This shows that informational role and decisional role has an important role to play in affecting employee job satisfaction at HQ Maybank Kuala Lumpur. Other than that, interpersonal role showed that results have no relationship with employee job satisfaction.

Finally, the highest t-value is decisional role, as indicated in Table 5 in previous section. This shows that managers at the chosen local bank Headquarters in Kuala Lumpur are able to make a right decision in any situation.

\section{References}

Abdullah, R., Musa, M., Zahari, H., Rahman, R., \& Khalid, K. (2011). The study of employee satisfaction and its effects towards loyalty in hotel industry in Klang Valley, Malaysia. International Journal of Business and Social Science, 2 (3), pp. 147-155.

Alatailat, M., Elrehail, H., \& Emeagwali, O. L. (2019). High performance work practices, organizational performance and strategic thinking. Int. Journal of Organizational Analysis.

Alkahtani, A. H. (2011). The impact of personality and leadership styles on leading change capability of Malaysian managers. Australian Journal of Business and Management Research, Vol. 8 No. 2, pp. 70-98.

Al-Sada, M., Al-Esmael, B., \& Faisal, R. (2017). Influence of organizational culture and leadership style on employee satisfaction, commitment and motivation in the educational sector in Qatar. EuroMed Journal of Business, pp. 163-188.

Annuar, H. (2011). The reationship between job satisfaction and job performance among employees in tradewinds group of companies. School Psychology Review, pp. 507-522.

Bakers, G. (2001). Organizational concepts and theories in the public sector. New York: Raleigh.

Blakely, G. L. (2003). Are chameleons good citizens?. A longitudinal study of the relationship between self-monitoring and organizational citizenship behavior. Journal of Business and Psychology, pp. 131-144.

Castillo, J. X. (2004). Factors explaining job satisfaction among faculty. Journal of Agricultural Education, pp. 65-74.

Chen, C. \& Wu. (2008). Importance of diversified leadership roles in improving team effectiveness in a virtual collaboration learning environment department of computer information systems. Educational Technology \& Society, pp. 304-321. 
INTERNATIONAL JOURNAL OF ACADEMIC RESEARCH IN ACCOUNTING, FINANCE AND

MANAGEMENT SCIENCES

Vol. 11, No. 3, 2021, E-ISSN: 2225-8329 @ 2021 HRMARS

Coplan, B., McCall, T. C., Smith, N., Gellert, V. L., \& Essary, A. C. (2018). Burnout, job satisfaction, and stress levels of PAs. Journal of the American Academy of PAs, 31(9), 42-46.

Cropanzo, R., \& Wright, T. (2000). Psychological well-being and job satisfaction as predictors of job performance. Journal of Occupational Health Psychology, pp. 84-94.

DeCremer, D. (2003). Why inconsistent leadership is regarded as procedurally unfair: the importance of social self-esteem concerns. European Journal of Social Psychology, pp. 535-550.

Dormann, C., and Zapf, D. (2001). Job satisfaction: A Meta-Analysis of Stabilities. Journal of Organizational Behavior, pp. 483-504.

Febres, G. E. (2017). Relationship between the Transactional Leadership Styles, the Transformational Leadership Style and Subordinates' Job Satisfaction (Doctoral dissertation, Northcentral University).

Hill, B. (2016). The Importance of Planning in an Organization.

Hugnes, R. G. (2006). Leadership, Enhancing the Lessons of Experience. Boston, MA: McGraw Hill.

Kalluvelil, J., Anju \& George, S. (2015). A Study on Job Satisfaction of Employees in BPCL. International Journal of Bank Marketing, pp. 58-77.

Kassahun, A. (2019). The Effect Of Relationship Marketing On Customer Loyalty (The Case Of Commercial Bank Of Ethiopia) (Doctoral dissertation, St. Mary's University).

Kiarie, M. A. W., Maru, L. C., \& Cheruiyot, T. K. (2017). Leader Personality Traits and Employee Job Satisfaction in The Media Sector, Kenya", The TQM Journal, Vol. 29, No. 1, pp. 133-146.

Krejcie, R. V., \& Morgan, D. W. (1970) Determining sample size for research activities. Educational and Psychological Measurement. 30 pp. 607-610

Mace, T. M. (2013). The Managerial Activities and Leadership Roles of Five Achieving the Dream Leader College President. Arkansas (Dissertation - D. Phil).

Mansor, A. N., Mansor, A. Z., \& Roslan, M. Z. (2019). Principals' Managerial Roles in Pontian District, Johor, Malaysia. Creative Education, Vol. 10 No. 3, pp. 3131-3141

Mariya, M., \& Svetlana, T. (2017). A Model of Skills and Activities for Modern Leaders and Managers in Enabling Managerial Leadership Process in Organizations. International Journal of Economics, Commerce and Management, pp. 63-94.

McConkey, H. (2002). What do entrepreneurs do? Journal of Business, pp. 300-316.

McGinn, H. (2003). An investigation into factors that influence job satisfaction of African American Librarians in some urban public library systems in the United States.

Ming-Chun, T., Ching-Chan, C., \& Ya-Yuan, C.. (2015). Drivers of Hospitality Industry Employees' Job Satisfaction, Organizational Commitment and Job Performance. African Journal of Business Management, pp. 4118-4134.

Mintzberg, H. (1973). Contemporary Views of The Manager's Job. The Nature of Managerial Work, pp. 104-116.

Mintzberg, H. (1990). The manager's job: Folklore and fact. Harvard Business Review, pp. 49-61.

Rad, M. A. M., \& Yarmohammadian, M. H. (2006). A study of relationship between managers' leadership style and employees' job ssatisfaction. Leadership in Health Services, Vol. 19, No. 2, pp. xi-xxviii.

Paul, S. (2017). Exploring Mintzberg's managerial roles of academic leaders. South Africa: North-West University 
INTERNATIONAL JOURNAL OF ACADEMIC RESEARCH IN ACCOUNTING, FINANCE AND

MANAGEMENT SCIENCES

Vol. 11, No. 3, 2021, E-ISSN: 2225-8329 @ 2021 HRMARS

Rania, A., Taghrid S., \& Mohammed, A. (2018) Learning Organizations and Innovation Mediated by Job Satisfaction. International Journal of Business and Economics Research. Vol. 7, No. 1, pp. 719.

Rahman, U. H. F. B. (2019). Diversity management and the role of leader. Open Economics. 2 (1), pp. 30-39.

Rahman, K. U., Akhter, W., \& Khan, S. U. (2017). Factors affecting employee job satisfaction: A comparative study of conventional and Islamic insurance. Cogent Business \& Management, 4(1), 1273082.

Ribelin, P. J. (2003). Retention reflects leadership style. Nursing Management, pp. 18-20.

Robbins, S. P. \& Judge, T. A. (2008). Essentials of Organizational Behavior. New Jersey: Pearson Education.

Shehawy, Y. E. (2018). Factors affecting employees' job embeddedness in the Egyptian airline industry. Tourism Review, pp. 548-571.

Smith, P. C., Kendall, L. M., \& Hullin, C. L. (1969) The Measurement of Satisfaction in Work and Retirement. Chicago: Rand McNally.Sturgeon, J. (2006). Springing for Training. Washington.

Thaoprom, P. (2004). Relationship Between Quality of Work Life and Job Performance for Police Office-Crime Prevention and Suppression Division: Case Study Thonglor Metropolitan (Doctoral dissertation, Mahidol University).

Tovmasyan, G. (2017). The Role of Managers in Organizations: Psychological Aspects. Business Ethics and Leadership, Vol. 1, Issue 3, pp. 20-26.

Welch, A. B. (2002). Temperament and Competence in The Managerial Roles of Nursing Education Administrators in The North Carolina Community College System. 